University of Nebraska - Lincoln

DigitalCommons@University of Nebraska - Lincoln

Occurrence And Potential Adverse Effects Of Semivolatile Organic Compounds In Streambed Sediment, United States, 1992-1995

Thomas J. Lopes

U.S. Geological Survey, tjlopes@usgs.gov

Edward T. Furlong

U.S. Geological Survey, National Water-Quality Laboratory

Follow this and additional works at: https://digitalcommons.unl.edu/usgsstaffpub

Part of the Earth Sciences Commons

Lopes, Thomas J. and Furlong, Edward T., "Occurrence And Potential Adverse Effects Of Semivolatile Organic Compounds In Streambed Sediment, United States, 1992-1995" (2001). USGS Staff -- Published Research. 513.

https://digitalcommons.unl.edu/usgsstaffpub/513

This Article is brought to you for free and open access by the US Geological Survey at DigitalCommons@University of Nebraska - Lincoln. It has been accepted for inclusion in USGS Staff -- Published Research by an authorized administrator of DigitalCommons@University of Nebraska - Lincoln. 


\title{
OCCURRENCE AND POTENTIAL ADVERSE EFFECTS OF SEMIVOLATILE ORGANIC COMPOUNDS IN STREAMBED SEDIMENT, UNITED STATES, 1992-1995
}

\author{
ThOMAS J. LOPES*† and Edward T. FurLONGł \\ $\dagger$ †.S. Geological Survey, 333 West Nye Lane, Carson City, Nevada 89706 \\ \$U.S. Geological Survey, National Water-Quality Laboratory, Box 25046, Denver Federal Center, Denver, Colorado 80225-0046
}

(Received 4 February 2000; Accepted 29 August 2000)

\begin{abstract}
The occurrence and potential adverse effects of select semivolatile organic compounds (SVOCs) in streambed sediment were assessed at 536 sites in 20 major river basins across the United States from 1992 to 1995. Fifty-six SVOCs were detected at one or more sites, and one or more SVOCs were detected at $71 \%$ of sites. The northeastern and Great Lakes regions and large metropolitan areas have the highest SVOC concentrations. Polycyclic aromatic hydrocarbons (PAHs) were detected most frequently and at the highest concentrations. Concentrations of PAHs and phthalates were about 10 times higher at sites influenced by urban activities than at sites in other land-use areas. Semivolatile organic compounds were significantly $(\alpha=0.05)$ correlated with land use and population density, and PAHs also correlated with physical/chemical properties. On the basis of sediment-quality guidelines, adverse effects are probable at $7.5 \%$ and possible at $16.2 \%$ of the sites. Most of the potential for adverse effects is due to PAHs. The median percentage of urban land use was $8 \%$ at sites with possible adverse effects and $16 \%$ at sites with probable adverse effects. Urbanization profoundly affects sediment quality, even though it comprised a small percentage of most drainage basins.
\end{abstract}

Keywords-Sediment Streams Polycyclic aromatic hydrocarbon Phthalate Urban

\section{INTRODUCTION}

One long-term objective of the U.S. Geological Survey's National Water-Quality Assessment (NAWQA) Program is to assess the quality of sediment in the nation's streams [1]. Bed sediment from streams in major river basins across the United States is being assessed for the occurrence and distribution of semivolatile organic compounds (SVOCs), organochlorine pesticides and polychlorinated biphenyls [2], and trace elements [3]. In general, these are hydrophobic compounds that preferentially distribute into hydrophobic organic phases, such as sediment organic carbon and lipids in animal tissue. Streams were sampled in drainage basins with different land uses, including basins that are relatively unaffected by human activities, to assess the quality of sediment in a variety of environments. Sites with known localized contamination were not targeted because the emphasis is to characterize concentrations that occur over large geographic areas. The major river basins in the United States are organized into three groups such that most regions of the nation are represented in each group. During a nine-year cycle, the three groups rotate through threeyear phases of intensive data collection. The quality of stream sediment in a variety of land-use settings will be well represented when the first cycle of assessments is completed in 2001.

This paper summarizes the occurrence and potential adverse effects of select SVOCs in the first group of 20 major river basins (Fig. 1). The 65 selected SVOCs includes 27 polycyclic aromatic hydrocarbons (PAHs), 11 halogenated compounds, 7 azaarenes, 6 phthalates, 6 phenols, 6 nitrogenated compounds, 1 quinone, and 1 cyclic ketone. By definition, SVOCs have low to moderate vapor pressures [4]. The SVOCs are operationally defined as solvent-extractable organic compounds that

* To whom correspondence may be addressed (tjlopes@usgs.gov)

Any use of trade names is for descriptive purposes only and does not imply endorsement by the U.S. government. can be determined by gas chromatography/mass spectrometry [5]. Many of the SVOCs that were analyzed are priority pollutants, which are compounds that received special attention when the process of setting water-quality standards and effluent limits were initiated in the 1970s [6]. Many of the priority pollutants are toxic compounds that are commonly associated with industrial activities and processes and are referenced in the Clean Water Act of 1977. Priority pollutants that are SVOCs include phthalates used in plastics, phenols used in disinfectants and in manufacturing chemicals, and PAHs. Polycyclic aromatic hydrocarbons and azaarenes are comprised of fused benzene rings that form during the incomplete combustion of organic matter, including wood and fossil fuels, such as gasoline, coal, and fuel oil [7]. Azaarenes are distinguished from PAHs by having a nitrogen atom substituted for a carbon atom in the fused-ring structure. Azaarenes covary strongly with PAHs in bed-sediment samples [8] because fossil fuel combustion is the predominant source of PAHs and azaarenes. However, natural or anthropogenic introduction of uncombusted oil and coal and industrial use of PAHs in dye and plastic industries also could introduce PAHs to sediments $[9,10]$.

Some PAHs, phthalates, and phenols are probable human carcinogens and endocrine disruptors [11]. Endocrine disruptors can alter the hormone chemistry of certain species and endanger their long-term survival by affecting metabolic, developmental, and reproductive functions [12]. The primary routes of human exposure to SVOCs are ingestion of contaminated food and inhalation of contaminated air [7,11]. Although concentrations may be low, contaminants often occur together in the environment [13], and they can have additive toxic effects. For example, some PAHs and the pesticide chlorpyrifos co-occur in dust around homes and have additive effects on acetylcholinesterase activity [14].

Semivolatile organic compounds may accumulate in sediment to concentrations that are toxic to benthic organisms 


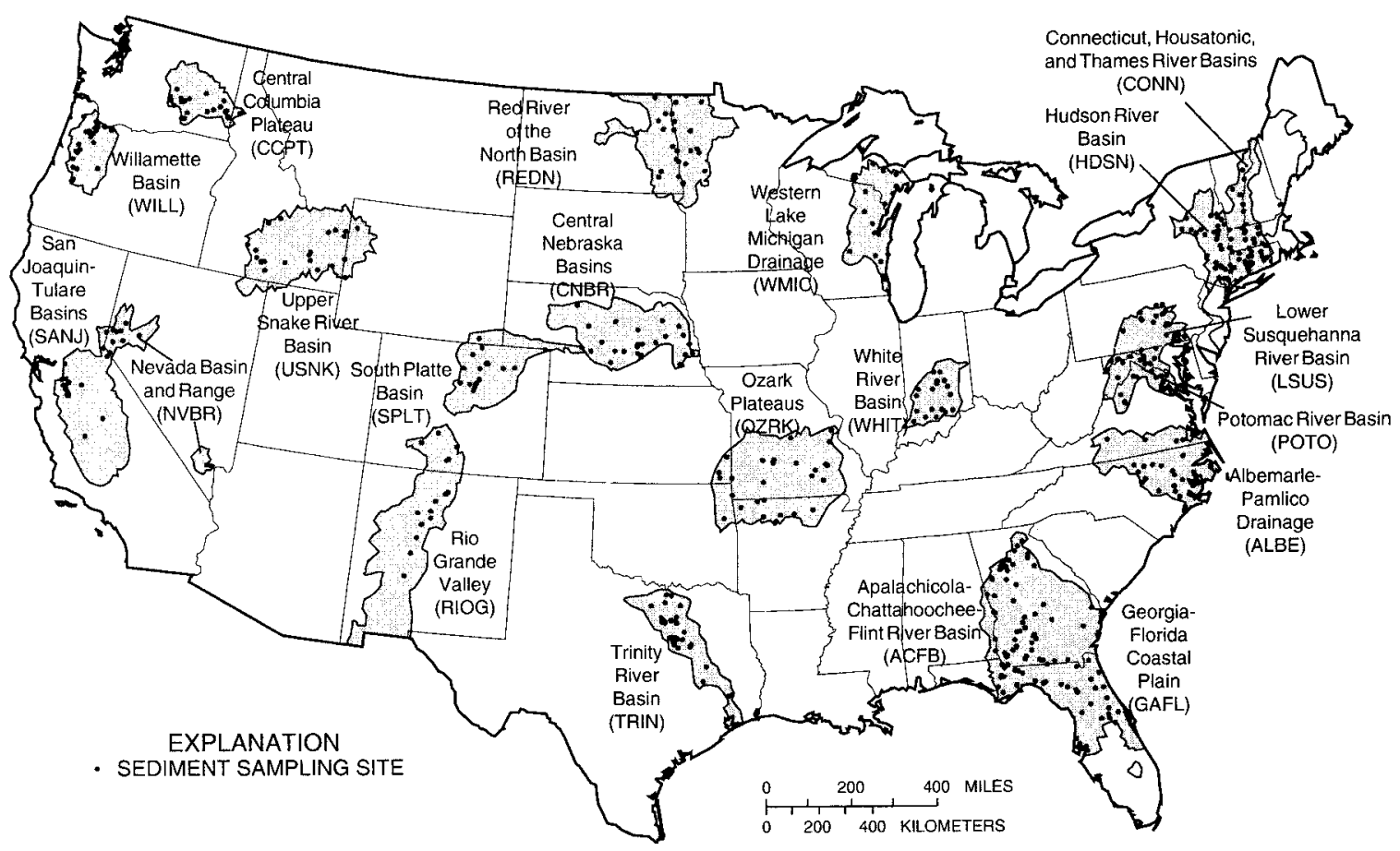

Fig. 1. Location of U.S. Geological Survey's National Water-Quality Assessment study areas and streambed sediment sites, 1992 to 1995.

$[15,16]$. To protect ecosystems from sediment contamination, sediment-quality guidelines (SQGs) have been developed for many contaminants and for total PAHs $[17,18]$. The SQGs are contaminant concentrations based on sediment dry weight or sediment organic carbon. Bioconcentration factors in fish and water fleas for most of the 65 SVOCs are between 10 and 1,000 [19]. In contrast, many organochlorine pesticides and polychlorinated biphenyls are less readily metabolized by organisms and have bioconcentration factors between 1,000 and 100,000. This explains why SQGs generally are higher for SVOCs than for organochlorine pesticides and polychlorinated biphenyls.

\section{STUDY METHODS}

\section{Streambed-sediment samples}

Streambed-sediment samples were collected from 536 sites in the 20 major river basins between August 1992 and September 1995. Replicate samples were collected at 52 of these sites. All streambed-sediment samples and replicates were collected using consistent methods [20] to determine which constituents are associated with different land uses over a wide geographic area. The sampling protocol targeted depositional zones with fine-grained, organic carbon-rich sediment [20]. At each sampling site, 5 to 10 samples were collected from depositional zones in a 100-m reach of a stream, composited, and then sieved to $<2 \mathrm{~mm}$ using a stainless-steel sieve. Only the surficial 2 to $3 \mathrm{~cm}$ of streambed sediment were sampled in order to characterize concentrations of SVOCs in recently deposited sediments. Samples were placed in precleaned glass jars with Teflon ${ }^{\circledR}$-lined lids, shipped to the laboratory on ice, and stored frozen until analysis. Some sites were sampled more than once, in which case the first sample collected at the site was used in this analysis. The number of sites sampled in each river basin (Fig. 1) ranged from 13 to 55 with a median of
24. The drainage basin upstream from sampled sites had a median area of $700 \mathrm{~km}^{2}$.

Agriculture was the targeted land use in the first 20 river basins. Agriculture and forest comprised $80 \%$ or more of the land use in the drainage basin at about $60 \%$ of the sites. Urban and rangeland comprised substantial percentages of the land use at most other sites. Agriculture, forest, urban, and rangeland comprised about $80 \%$ or more of the land use in the drainage basins at about $90 \%$ of the sites.

\section{Chemical analysis}

The analytical procedure and method performance are described in detail by Furlong et al. [5]. Briefly, streambedsediment samples were extracted with dichloromethane in a Soxhlet apparatus for at least $12 \mathrm{~h}$. The extract was concentrated, and SVOCs were then partially isolated from humictype compounds and elemental sulfur by an automated gel permeation chromatography system. Internal standards were added to the concentrated SVOC extract, and the extract was analyzed by gas chromatography/mass spectrometry. The mass spectrometer was operated in full-scan mode with electronimpact ionization. The mean method detection limit, calculated according to the protocol of the U.S. Environmental Protection Agency's (U.S. EPA) [21], is $30 \mu \mathrm{g} / \mathrm{kg}$ with a standard deviation of $13 \mu \mathrm{g} / \mathrm{kg}$. When not detected, all SVOCs were censored at the lowest daily calibration standard of $50 \mu \mathrm{g} / \mathrm{kg}$ for a target sample of $25 \mathrm{~g}$.

An independent check of method performance was provided by analysis of Standard Reference Material 1941([SRM], Gaithersburg, MD, USA), an estuarine sediment with $18 \mathrm{PAH}$ concentrations certified by the National Institute of Standards and Technology ([NIST], Gaithersburg, MD, USA). Recoveries of PAHs from SRM 1941 ranged from 51 to $120 \%$ with a mean of $83 \%$. The relative standard deviation of recovery ranged from 20 to $104 \%$ with a mean of $53 \%$. The mean and 
standard deviations of recoveries compared well with values provided by NIST, indicating that the method performs similarly to the method used by NIST. The SRM 1941 also is included in each set of sample analyses as part of laboratory quality control. Recoveries from SRM during 1992-1995 compared well with values provided by NIST, indicating that the method performed well throughout the study.

In sediment samples spiked at $800 \mu \mathrm{g} / \mathrm{kg}$, recoveries of the 65 SVOCs ranged from 18 to $120 \%$ with a mean of $79 \%$. At $2,000 \mu \mathrm{g} / \mathrm{kg}$, spike recoveries ranged from 6.8 to $70 \%$ with a mean of $57 \%$. Polycyclic aromatic hydrocarbons, azaarenes, phenols, dimethyl phthalate, and diethyl phthalate comprised most of the compounds that had recoveries greater than $80 \%$ when spiked at $800 \mu \mathrm{g} / \mathrm{kg}$. Chlorinated compounds, bis(2ethylhexyl) phthalate, and di- $n$-octyl phthalate comprised most of the compounds that had recoveries $<50 \%$. Detected concentrations in environmental samples were not corrected for recovery.

Five compounds were detected in 30 to $80 \%$ and 60 compounds were detected in 0 to $3 \%$ of 68 laboratory blank samples [5]. For this paper, laboratory contamination was corrected by subtracting the 95th-percentile concentration of laboratory blank samples analyzed between 1992 and 1995 from the concentration detected in environmental samples. Differences $<50$ $\mu \mathrm{g} / \mathrm{kg}$ were censored. The five SVOCs frequently detected in laboratory blanks and their 95th-percentile concentrations of laboratory blank samples are phenol (27 $\mu \mathrm{g} / \mathrm{kg})$, diethyl phthalate $(25 \mu \mathrm{g} / \mathrm{kg})$, di- $n$-butyl phthalate $(54 \mu \mathrm{g} / \mathrm{kg})$, butylbenzyl phthalate $(64 \mu \mathrm{g} / \mathrm{kg})$, and bis(2-ethylhexyl) phthalate $(100 \mu \mathrm{g} / \mathrm{kg})$.

\section{Replicate samples}

Except for naphthalene, sign-rank tests indicated no significant difference in SVOC concentrations between replicate samples. If both replicates had detected concentrations greater than $50 \mu \mathrm{g} / \mathrm{kg}$, then the percentage difference between replicates was calculated by dividing the difference by the average of the two concentrations and multiplying by 100 . The median difference in naphthalene concentrations was $12 \%(n=6)$. Median differences were $14 \%$ for PAHs $(n=304), 12 \%$ for azaarenes $(n=22), 18 \%$ for phthalates $(n=61)$, and $18 \%$ for phenols $(n=29)$. Lack of a significant difference between replicate samples, except for naphthalene, and the low percentage differences indicate that results are reproducible.

\section{Data analysis}

Detection frequencies and percentiles of SVOC concentrations were computed at the censoring level of $50 \mu \mathrm{g} / \mathrm{kg}$. Sums of SVOCs were computed assuming that censored concentrations were equal to zero. In most data analyses, nonparametric statistics were used because results are not affected by extreme values or conventions of handling censored values [22]. A sign-rank test was performed using data from the 52 replicate samples to determine whether results of sampling and chemical analyses are reproducible. Spearman rank correlations were used to determine relations among SVOC concentrations and relations between SVOC and sediment organic carbon concentrations. The Kruskal-Wallis test was used to compare concentrations among river basins and among sites influenced by a single land use, sites with a mixture of land uses, and point sources. Forest and reference sites are relatively undisturbed by human activities. Statistical results were considered significant at $\alpha=0.05$.
To evaluate the potential for adverse effects, screening values were chosen from among the SQGs to distinguish stream sites where the toxicity of sediments to aquatic organisms is unlikely, possible, or probable. Survival was the most common end point used to develop SQGs; however, growth, reproduction, deformities, and luminescence also were measured [18]. Adverse effects are unlikely for concentrations less than the lower screening value and probable for concentrations greater than the upper screening values. Adverse effects are possible for sediment concentrations between the lower and upper screening values. However, these screening values may be under- or overprotective of aquatic biota, depending on site-specific conditions, and some of the screening values were developed for marine sediments. First, consensus-based freshwater SQGs [18] were chosen for certain individual PAHs and total PAHs. Consensus-based SQGs were evaluated using sediment chemistry and toxicity data from freshwater ecosystems in the United States. More than $75 \%$ of sediments were nontoxic when concentrations were less than the lower screening value, and more than $75 \%$ were toxic when concentrations were greater than the upper screening value [18]. Second, screening values for other SVOCs were selected from among marine SQGs using the same procedure as that of the U.S. EPA [17]. Briefly, the lower screening value is the lowest of as many as four values, including the effects range-low, apparent effects threshold-low, sediment-quality advisory level, and threshold effects level. The upper screening value is the second lowest of the effects range-median, apparent effects threshold-high, sediment-quality advisory level, and the probable effects level. The SQGs are based on dry sediment weight except the sediment-quality advisory level, which has units of $\mu \mathrm{g} / \mathrm{g}$ organic carbon. The sediment-quality advisory level was compared to other SQGs assuming 1\% sediment organic carbon. Only one SQG is needed for a compound in order to select a lower screening value, and at least two SQGs are needed to select an upper screening value. A total of 20 upper screening values and 35 lower screening values were compared to SVOC concentrations in streambed sediments.

Polycyclic aromatic hydrocarbons usually are present as a mixture, and their toxicity is additive [23]. Therefore, proposed sediment-quality criteria for individual PAHs may underprotect benthic organisms. In recognition of the common co-occurrence and additive toxicity of PAHs, the U.S. EPA has withdrawn proposed sediment-quality criteria for individual PAHs and may develop sediment-quality criteria for total PAHs or mixtures of PAHs [23]. In order to develop sedimentquality criteria for specific PAH mixtures, it is necessary to know which PAHs commonly co-occur. Therefore, a nonparametric cluster analysis [24] was performed using all positive detections to determine commonly co-occurring PAHs in streambed sediment. This cluster analysis uses binary data, such as detection or nondetection of a compound, to group observations that are similar. The degree of similarity among the observations is measured by the $r^{2}$ value. An $r^{2}$ value of 1.0 indicates a high degree of co-occurrence, and a value of -1.0 indicates an absence of co-occurrence.

\section{Comparison studies}

Results from NAWQA were compared to three other studies of sediment quality with a national scope, including the Environmental Monitoring and Assessment Program-Estuaries (EMAP-E) $[25,26]$, the National Status and Trends (NST) Program [27,28], and the National Sediment Quality Survey 
(NSQS) [17]. The EMAP-E and NST studies focused solely on estuarine or marine sediments. The U.S. EPA EMAP-E used a random sampling design to assess estuarine sediment quality and was not biased toward contaminated areas. In contrast, the National Oceanic and Atmospheric Administration's (NOAA) NST assessed marine sediments from mostly urban coastal waterways. The EMAP-E and NST sediment samples were not sieved, but samples had about $99 \%$ sand size $(2 \mathrm{~mm})$ and finer, which is the size fraction that was analyzed in sieved streambed-sediment samples (EMAP-E data were retrieved from http: //www.epa.gov/emap/ in April 1999; NST data were retrieved from http://www-orca.nos.noaa.gov/projects/msandt/rawdata.html in April 1999). The NSQS compiled freshwater and marine sediment data from many monitoring programs and compared data to SQGs to determine where contamination has unlikely, possible, and probable adverse effects on aquatic ecosystems and humans [17]. Adverse effects were probable or possible at about $75 \%$ of the 21,096 sites evaluated [17], most of which are east of the Mississippi River or in California and Washington, USA. The high percentage of sites with probable or possible adverse effects reflects the focus of monitoring programs on areas of known or suspected contamination, which is consistent with the objective of the NSQS. However, because geographic regions and uncontaminated sites are not evenly represented, the NSQS cannot be used to "accurately make inferences regarding the overall condition of the Nation's sediment, or characterize the "percent contamination" ", of the nation's sediment [17].

\section{OCCURRENCE OF SVOCS}

Of the 65 SVOCs measured, 56 were detected above the censoring level at one or more sites (Table 1). The PAH fluoranthene, detected at $39.8 \%$ of sites, was the most frequently detected SVOC. Thus, median concentrations for all SVOCs were $<50 \mu \mathrm{g} / \mathrm{kg}$. Detection frequencies for halogenated and nitrogenated compounds ranged from 0 to $1.2 \%$ with maximum concentrations of $<50$ to $190 \mu \mathrm{g} / \mathrm{kg}$. One or more SVOCs were detected at or above the censoring level at $71 \%$ of the sites. The median number of SVOCs detected in a sample was 2 and the maximum number of detections was 42 . The sum of all SVOCs had a median concentration of $260 \mu \mathrm{g} / \mathrm{kg}$ and ranged from 0 to $180,000 \mu \mathrm{g} / \mathrm{kg}$, and PAHs comprised most of the sum. The median sum of concentrations was $61 \mu \mathrm{g} / \mathrm{kg}$ for PAHs and $0 \mu \mathrm{g} / \mathrm{kg}$ for all other classes of SVOCs.

The Kruskal-Wallis test indicated that the sum of all SVOC concentrations in the Connecticut, Housatonic, and Thames River Basins (CONN) and Hudson River Basin (HDSN) (Fig. 1) are similar and higher than the other 18 river basins. Six river basins-Lower Susquehana River Basin (LSUS), Nevada Basin and Range (NVBR), Potomac River Basin (POTO), South Platte Basin (SPLT), White River Basin (WHIT), and West Lake Michigan Drainage (WMIC)—-have similar sums of SVOCs that are intermediate between the high concentrations in the CONN and HDSN and the other 12 river basins. High and intermediate SVOC concentrations occur mostly in the urban and industrial northeastern and Great Lakes regions and in river basins with large metropolitan areas, such as Denver, Colorado (SPLT), and Las Vegas, Nevada (NVBR).

\section{SVOCs and organic carbon}

Organic carbon in streambed sediment had a median concentration of $1.6 \%$ and ranged from 0.14 to $23 \%$. Marine sediments had slightly lower sediment organic carbon concentra- tions. Median and maximum sediment organic carbon concentrations were 1.2 and $13.7 \%$, respectively, for NST sites and 1.0 and $17 \%$, respectively, for EMAP-E sites. Rank correlations were significant and weak $\left(r^{2}<0.4\right)$ or not significant between sediment organic carbon and individual SVOCs, the sum of all SVOCs, and the number of SVOCs detected. Rank correlations between sediment organic carbon and the sum of all SVOCs were significant and fair $\left(0.4 \leq r^{2}<0.7\right)$ in 6 and not significant in 14 river basins. River basins with fair correlations were the CONN, HDSN, WHIT, Ozark Plateaus (OZRK), Red River of the North Basin (REDN), and San Joaquin-Tulare Basins (SANJ). In comparison, rank correlations between the sum of PAHs and sediment organic carbon were significant and fair in the Carolinian and Virginian EMAP-E study areas and for NST sites; the correlation was significant and weak in the Louisiana EMAP-E study area. It is difficult to explain generally lower correlations in streams compared to marine environments because the grain size and sediment organic carbon concentrations were similar. Although organic carbon content has been suggested as a primary variable controlling sedimentary SVOC concentrations [4], it is not the only factor that can affect sediment SVOC concentrations [29]. In this paper, SVOC concentrations were not normalized for organic carbon because correlations generally were weak or not significant.

\section{PAHs and azaarenes}

The frequency of detection ranged from 0.6 to $39.8 \%$ for the 27 PAHs and from 0.4 to $12.6 \%$ for the seven azaarenes (Table 1). Fluoranthene was the most frequently detected PAH and also had the highest concentration $(26,000 \mu \mathrm{g} / \mathrm{kg})$ of all SVOCs. The compound $9 \mathrm{H}$-carbazole was the most frequently detected azaarene and had the highest concentration among the azaarenes $(1,400 \mu \mathrm{g} / \mathrm{kg})$. Most rank correlations among individual PAHs, azaarenes, and sum of PAHs were significant and strong $\left(r^{2} \geq 0.7\right)$. The strong relations indicate a source that is common to various areas of the United States, which is likely the incomplete combustion of organic matter.

Within each class of SVOCs, higher-molecular-weight organic compounds generally have higher octanol-water and organic carbon partition coefficients, have lower water solubilities and Henry's law constants, and take longer to degrade than lighter compounds [19]. Among PAHs, azaarenes, phthalates, and phenols, PAHs are the most hydrophobic and persistent class of compounds [19]. The physical/chemical properties of PAHs and the widespread use of fossil fuels likely account for the frequent detection of PAHs in streambed sediment. Percentage detection of PAHs had significant and fair to strong positive rank correlations with molecular weight, the aerobic degradation half-life (Fig. 2a), and the organic carbon (Fig. 2b) and octanol-water partition coefficients. Percentage detection of PAHs had fair to strong inverse rank correlations with water solubility and Henry's law constant (Fig. 2c and d). These are the expected relations and are evidence that physical/chemical properties are important factors affecting the detection of SVOCs.

The substitution of a nitrogen atom in the fused-ring structure has a large effect on the physical/chemical properties of azaarenes. For example, quinoline, an azaarene, and naphthalene, a PAH, are the simplest compounds in each class and differ only by a nitrogen atom in the two fused benzene rings. However, the solubility of quinoline is about 200 times greater than the solubility of naphthalene [19]. Their higher solubility 
Table 1. Statistical summary of semivolatile organic compounds in streambed sediment of the United States, 1992-1995

\begin{tabular}{|c|c|c|c|c|c|c|c|c|}
\hline \multirow[b]{2}{*}{ CAS no. ${ }^{a}$} & \multirow[b]{2}{*}{ Compound name } & \multirow[b]{2}{*}{ Compound class } & \multirow{2}{*}{$\begin{array}{l}\text { No. of } \\
\text { sites }\end{array}$} & \multirow{2}{*}{$\begin{array}{l}\text { Percentage } \\
\text { detection }\end{array}$} & \multicolumn{4}{|c|}{$\begin{array}{l}\text { Concentration, in } \mu \mathrm{g} / \mathrm{kg} \text { dry wt at the } \\
\text { given percentile and maximum value }\end{array}$} \\
\hline & & & & & 75 th & 90th & 95 th & Maximum \\
\hline $206-44-0$ & Fluoranthene & $\mathrm{PAH}^{\mathrm{b}}$ & 498 & 39.8 & 170 & 1,000 & 2,700 & 26,000 \\
\hline $129-00-0$ & Pyrene & PAH & 496 & 37.9 & 140 & 780 & 2,000 & 21,000 \\
\hline $106-44-5$ & $p$-Cresol & Phenol & 505 & 37.8 & 99 & 430 & 870 & 4,800 \\
\hline $205-99-2$ & Benzo $[b]$ fluoranthene & PAH & 533 & 36.8 & 92 & 460 & 1,400 & 12,000 \\
\hline $218-00-9$ & Chrysene & $\mathrm{PAH}$ & 521 & 35.7 & 120 & 570 & 1,400 & 16,000 \\
\hline $207-08-9$ & Benzo $[k]$ fluoranthene & $\mathrm{PAH}$ & 532 & 33.1 & 84 & 400 & 1,100 & 10,000 \\
\hline $50-32-8$ & Benzo $[a]$ pyrene & PAH & 535 & 32.9 & 80 & 350 & 1,000 & 9,900 \\
\hline $85-01-8$ & Phenanthrene & $\mathrm{PAH}$ & 506 & 30.8 & 78 & 500 & 1,400 & 15,000 \\
\hline $218-00-9$ & Benz $[a]$ anthracene & PAH & 518 & 30.7 & 79 & 430 & 1,100 & 12,000 \\
\hline $117-81-7$ & Bis(2-Ethylhexyl)phthalate ${ }^{c}$ & Phthalate & 536 & 30.0 & 98 & 540 & 1,000 & 17,000 \\
\hline $193-39-5$ & Indeno $[1,2,3-c d]$ pyrene & PAH & 500 & 27.8 & 63 & 370 & 710 & 8,400 \\
\hline $581-42-0$ & 2,6-Dimethylnaphthalene & Alkyl-PAH & 490 & 25.7 & 50 & 97 & 140 & 930 \\
\hline $191-24-2$ & Benzo[ghi]perylene & PAH & 526 & 23.4 & $<50$ & 200 & 480 & 6,700 \\
\hline $84-65-1$ & Anthraquinone & Quinone & 500 & 22.2 & $<50$ & 150 & 420 & 2,100 \\
\hline $120-12-7$ & Anthracene & PAH & 533 & 22.0 & $<50$ & 150 & 520 & 4,100 \\
\hline $53-70-3$ & Dibenz $[a, h]$ anthracene & PAH & 524 & 16.8 & $<50$ & 130 & 280 & 4,400 \\
\hline $203-64-5$ & 4,5-Methylenephenanthrene & Alkyl-PAH & 487 & 14.4 & $<50$ & 100 & 290 & 2,100 \\
\hline $2381-21-7$ & 1-Methylpyrene & Alkyl-PAH & 482 & 13.5 & $<50$ & 78 & 200 & 2,500 \\
\hline $117-84-0$ & Di- $n$-ocytlphthalate & Phthalate & 488 & 13.3 & $<50$ & 70 & 110 & 1,100 \\
\hline $208-96-8$ & Acenaphthylene & $\mathrm{PAH}$ & 535 & 12.9 & $<50$ & 77 & 170 & 1,500 \\
\hline $832-69-9$ & 1-Methylphenanthrene & Alkyl-PAH & 487 & 12.9 & $<50$ & 81 & 200 & 3,900 \\
\hline $86-74-8$ & 9H-Carbazole & Azaarene & 494 & 12.6 & $<50$ & 81 & 180 & 1,400 \\
\hline $86-73-7$ & 9H-Fluorene & PAH & 518 & 10.4 & $<50$ & 53 & 140 & 6,700 \\
\hline $613-12-7$ & 2-Methylanthracene & Alkyl-PAH & 497 & 10.3 & $<50$ & 54 & 130 & 3,600 \\
\hline $108-95-2$ & Phenol $^{c}$ & Phenol & 536 & 10.1 & $<50$ & 50 & 100 & 210 \\
\hline $83-32-9$ & Acenaphthene & PAH & 530 & 10.0 & $<50$ & 51 & 94 & 1,500 \\
\hline $260-94-6$ & Acridine & Azaarene & 501 & 9.8 & $<50$ & $<50$ & 91 & 500 \\
\hline $132-65-0$ & Dibenzothiophene & Sulfurous-PAH & 498 & 8.4 & $<50$ & $<50$ & 100 & 1,300 \\
\hline $91-20-3$ & Naphthalene & PAH & 496 & 7.7 & $<50$ & $<50$ & 78 & 4,900 \\
\hline $229-87-8$ & Phenanthridine & Azaarene & 503 & 7.2 & $<50$ & $<50$ & 62 & 380 \\
\hline $575-43-9$ & 1,6-Dimethylnaphthalene & Alkyl-PAH & 492 & 6.3 & $<50$ & $<50$ & 56 & 680 \\
\hline $85-68-7$ & Butylbenzylphthalate & Phthalate & 536 & 5.6 & $<50$ & $<50$ & 76 & 2,240 \\
\hline $84-74-2$ & Di- $n$-butylphthalate & Phthalate & 536 & 4.8 & $<50$ & $<50$ & $<50$ & 260 \\
\hline $1730-37-6$ & 1-Methyl-9H-fluorene & Alkyl-PAH & 503 & 4.2 & $<50$ & $<50$ & $<50$ & 590 \\
\hline $829-26-5$ & 2,3,6-Trimethylnaphthalene & Alkyl-PAH & 490 & 2.8 & $<50$ & $<50$ & $<50$ & 360 \\
\hline $119-91-5$ & $2,2^{\prime}$-Biquinoline & Azaarene & 487 & 2.5 & $<50$ & $<50$ & $<50$ & 400 \\
\hline $119-65-3$ & Isoquinoline & Azaarene & 489 & 2.2 & $<50$ & $<50$ & $<50$ & 100 \\
\hline $939-27-5$ & 2-Ethylnaphthalene & Alkyl-PAH & 483 & 1.6 & $<50$ & $<50$ & $<50$ & 510 \\
\hline $120-83-2$ & 1,4-Dichlorobenzene & Chloro-aromatic & 518 & 1.2 & $<50$ & $<50$ & $<50$ & 140 \\
\hline $606-20-2$ & 2,6-Dinitrotoluene & Nitro-aromatic & 518 & 1.0 & $<50$ & $<50$ & $<50$ & 93 \\
\hline $108-68-9$ & 3,5-Dimethylphenol & Phenol & 488 & 1.0 & $<50$ & $<50$ & $<50$ & 150 \\
\hline $111-91-1$ & bis(2-Chloroethoxy)methane & Chloro-ether & 521 & 0.8 & $<50$ & $<50$ & $<50$ & 58 \\
\hline $95-57-8$ & 2-Chlorophenol & Phenol & 491 & 0.8 & $<50$ & $<50$ & $<50$ & 170 \\
\hline $131-11-3$ & Dimethylphthalate $^{c}$ & Phthalate & 521 & 0.6 & $<50$ & $<50$ & $<50$ & 120 \\
\hline $121-14-2$ & 2,4-Dinitrotoluene & Nitro-aromatic & 519 & 0.6 & $<50$ & $<50$ & $<50$ & 170 \\
\hline $95-50-1$ & 1,2-Dichlorobenzene & Chloro-aromatic & 516 & 0.6 & $<50$ & $<50$ & $<50$ & 86 \\
\hline $230-17-1$ & Benzo $[c]$ cinnoline & Azaarene & 491 & 0.6 & $<50$ & $<50$ & $<50$ & 340 \\
\hline $573-98-8$ & 1,2-Dimethylnaphthalene & Alkyl-PAH & 488 & 0.6 & $<50$ & $<50$ & $<50$ & 280 \\
\hline $156-10-5$ & N-Nitrosodiphenylamine & Nitroso-amine & 487 & 0.6 & $<50$ & $<50$ & $<50$ & 79 \\
\hline $103-33-3$ & Azobenzene & Nitro-aromatic & 492 & 0.4 & $<50$ & $<50$ & $<50$ & 130 \\
\hline $91-22-5$ & Quinoline & Azaarene & 487 & 0.4 & $<50$ & $<50$ & $<50$ & 83 \\
\hline$-\mathrm{d}$ & C8-Alkylphenol & Phenol & 487 & 0.4 & $<50$ & $<50$ & $<50$ & 100 \\
\hline $101-55-3$ & 4-Bromophenyl-phenylether & Bromo-ether & 518 & 0.2 & $<50$ & $<50$ & $<50$ & 130 \\
\hline $120-82-1$ & 1,2,4-Trichlorobenzene & Chloro-aromatic & 517 & 0.2 & $<50$ & $<50$ & $<50$ & 68 \\
\hline $82-68-8$ & Pentachloronitrobenzene & Chloro-aromatic & 516 & 0.2 & $<50$ & $<50$ & $<50$ & 180 \\
\hline $59-50-7$ & 4-Chloro-3-methylphenol & Phenol & 489 & 0.2 & $<50$ & $<50$ & $<50$ & 190 \\
\hline $1827-21-4$ & Pentachloroanisole & Chloro-aromatic & 534 & 0 & $<50$ & $<50$ & $<50$ & $<50$ \\
\hline 118-74-1 & Hexachlorobenzene & Chloro-aromatic & 534 & 0 & $<50$ & $<50$ & $<50$ & $<50$ \\
\hline $7005-72-3$ & 4-Chlorophenyl-phenylether & Chloro-ether & 518 & 0 & $<50$ & $<50$ & $<50$ & $<50$ \\
\hline $84-66-2$ & Diethylphthalate & Phthalate & 517 & 0 & $<50$ & $<50$ & $<50$ & $<50$ \\
\hline $91-58-7$ & 2-Chloronaphthalene & Chloro-aromatic & 516 & 0 & $<50$ & $<50$ & $<50$ & $<50$ \\
\hline $541-73-1$ & 1,3-Dichlorobenzene & Chloro-aromatic & 516 & 0 & $<50$ & $<50$ & $<50$ & $<50$ \\
\hline $78-79-1$ & Isophorone & Cyclic ketone & 488 & 0 & $<50$ & $<50$ & $<50$ & $<50$ \\
\hline $98-95-3$ & Nitrobenzene & Nitro-aromatic & 487 & 0 & $<50$ & $<50$ & $<50$ & $<50$ \\
\hline $621-64-7$ & $N$-nitrosodi- $n$-propylamine & Nitroso-amine & 487 & 0 & $<50$ & $<50$ & $<50$ & $<50$ \\
\hline
\end{tabular}

${ }^{a} \mathrm{CAS}=$ Chemical Abstract Services.

${ }^{\mathrm{b}} \mathrm{PAH}=$ polycyclic aromatic hydrocarbon.

${ }^{\mathrm{c}}$ Corrected for lab contamination.

${ }^{\mathrm{d}}-=$ CAS number does not exist. 

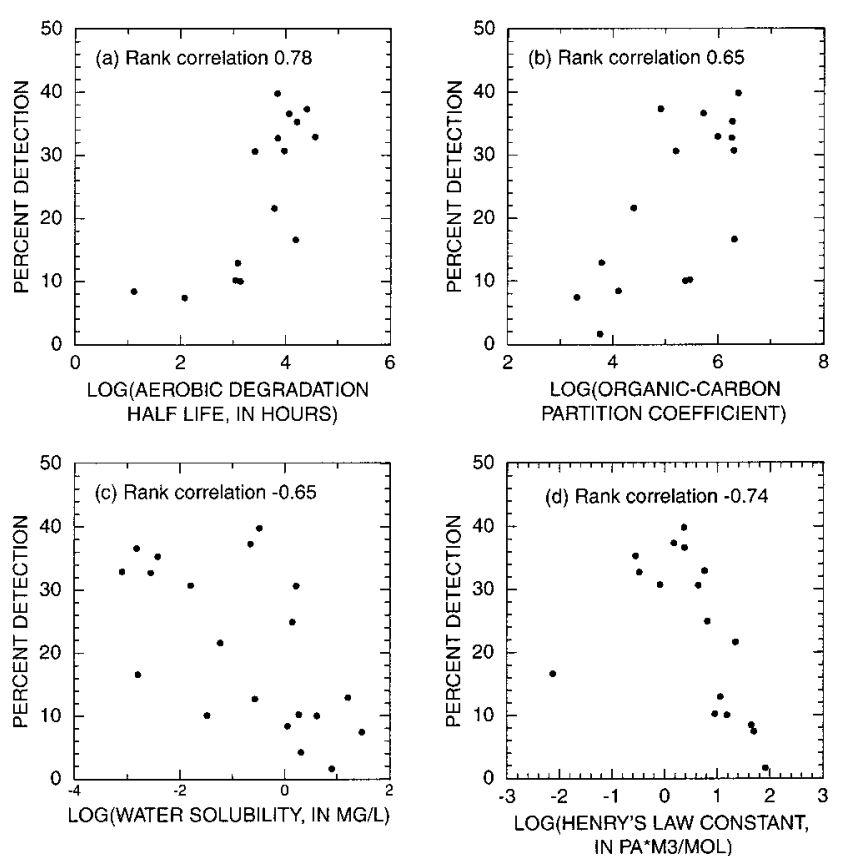

Fig. 2. Relations between physical/chemical properties and percentage detection of polycyclic aromatic hydrocarbons (PAHs).

could explain why azaarenes were detected less frequently in streambed sediment than PAHs. Polycyclic aromatic hydrocarbons were the only SVOCs that significantly correlated with physical/chemical properties, which could be because most other classes of SVOCs had only six or seven compounds to calculate correlations, and the 11 halogenated compounds were detected at $<2 \%$ of the sites.

The spatial distribution of PAHs (Fig. 3A) and azaarenes is similar to that of the sum of all SVOCs with highest concentrations in the northeastern and Great Lakes regions and large metropolitan areas. The median sum of PAHs was highest in the CONN $(6,100 \mu \mathrm{g} / \mathrm{kg})$ and $\operatorname{HDSN}(3,200 \mu \mathrm{g} / \mathrm{kg})$ and $<50$ $\mu \mathrm{g} / \mathrm{kg}$ in eight river basins in the southeastern, central, and western regions of the United States. The highest sum of PAHs $(170,000 \mu \mathrm{g} / \mathrm{kg})$ was measured near Milwaukee, Wisconsin, in the WMIC. The median sum of azaarenes was highest in the POTO $(120 \mu \mathrm{g} / \mathrm{kg})$ and CONN $(55 \mu \mathrm{g} / \mathrm{kg})$ and $<50 \mu \mathrm{g} / \mathrm{kg}$ in all other river basins. The highest sum of azaarenes $(2,300 \mu \mathrm{g} /$ $\mathrm{kg}$ ) was measured near Albany, New York, in the HDSN.

The Kruskal-Wallis test indicated that sites influenced by urban land use had significantly higher PAH concentrations, by about a factor of 10 , than other land uses except point sources (Fig. 4). This is consistent with NST data, which found PAH concentrations in urban waterways that are intermediate between the urban stream sites and all NAWQA and EMAPE sites (Fig. 5). The sum of PAHs in streambed sediment also had significant and fair correlations with urban-related factors such as population density in the drainage basin and within certain radii of the sites (Table 2). The PAH concentrations begin to increase when urban land use is about 1 to $3 \%$ of the drainage basin and population density is about 10 to 20 people/ $\mathrm{km}^{2}$ (Fig. 6). Concentrations increase the most between about 3 and $20 \%$ urban land use and about 20 and 200 people $/ \mathrm{km}^{2}$ and increase little with greater percentages of urban land use or population density. Rank correlations between the sum of PAHs and population density in the drainage basin and within a radius of 5 and $10 \mathrm{~km}$ of the sample site are similar. Cor- relations decrease with radii greater than $10 \mathrm{~km}$ around sample sites, indicating that local activities in and near the drainage basin affect sediment quality. The high PAH concentrations, significant correlations with urban-related factors, and low percentage of urban land use that results in contaminated sediment indicate that urban areas profoundly affect sediment quality. Approximately two-thirds of all metropolitan areas are in the eastern third of the country [30]. The large density of industry and urbanization likely explains the high PAH concentrations in the northeastern and Great Lakes regions.

\section{Phthalates}

Blank corrected concentrations of five of the six phthalates were detected above the censoring level at one or more sites. Bis(2-ethylhexyl) phthalate was the most frequently detected phthalate $(30.0 \%)$ and had the highest concentration $(17,000$ $\mu \mathrm{g} / \mathrm{kg}$ ). Most correlations among phthalates and between the sums of phthalates and PAHs were significant and fair to strong.

Similar to PAHs, the sums of phthalates were highest in the northeastern and Great Lakes regions and in large metropolitan areas (Fig. 3B). The median sum of phthalates was $<50 \mu \mathrm{g} / \mathrm{kg}$ in 15 river basins, and the highest concentration $(20,000 \mu \mathrm{g} / \mathrm{kg})$ was measured near Yonkers, New York, in the HDSN. Phthalate concentrations also were about 10 times higher at sites influenced by urban land use and point sources compared to other land uses (Fig. 4), and concentrations had significant and fair correlations with the percentage of urban land use and population density (Table 2). The similar spatial distribution and correlations between the phthalates and PAHs may result from these compounds being ubiquitous contaminants associated with urban activities [7,9] and because similar processes transport and accumulate phthalates and PAHs in streambed sediment. Phthalates are used in plastics, which are used primarily in urban areas.

\section{Phenols}

The most frequently detected phenols were $p$-cresol $(37.8 \%)$ and phenol $(10.1 \%)$. All other phenolic compounds were detected at $<1 \%$ of sites. The $p$-cresol and phenol had maximum concentrations of 210 and $4,800 \mu \mathrm{g} / \mathrm{kg}$, respectively. Concentrations of $p$-cresol and phenol were significantly correlated and concentrations significantly correlated with the sum of PAHs and phthalates (Table 2). All correlations were weak.

In contrast to PAHs and phthalates, no spatial relation was apparent for the sum of phenols (Fig. 3C). The median sum of phenols was $<50 \mu \mathrm{g} / \mathrm{kg}$ in 14 river basins, and the highest sum of phenols $(4,900 \mu \mathrm{g} / \mathrm{kg})$ was measured near Milwaukee, Wisconsin. The Kruskal-Wallis test indicated that sums of phenols were significantly different only between urban land use and mixed, agriculture, and forest/reference land uses (Fig. 4). The only significant correlation between the sum of phenols and land use and population density was a weak inverse correlation with the percentage of agriculture. The lack of a spatial relation and little difference in concentrations among land uses may reflect widespread use and/or natural sources of phenols. Phenols are extensively used in industrial, agricultural, and sanitary applications [31] and occur in vehicle exhaust, coal, petroleum, wood, and runoff from reference areas [32].

\section{POTENTIAL ADVERSE EFFECTS}

Screening values indicated that adverse effects of SVOCs on aquatic biota are probable at $7.5 \%$ of sites (Table 3 ). Sites 

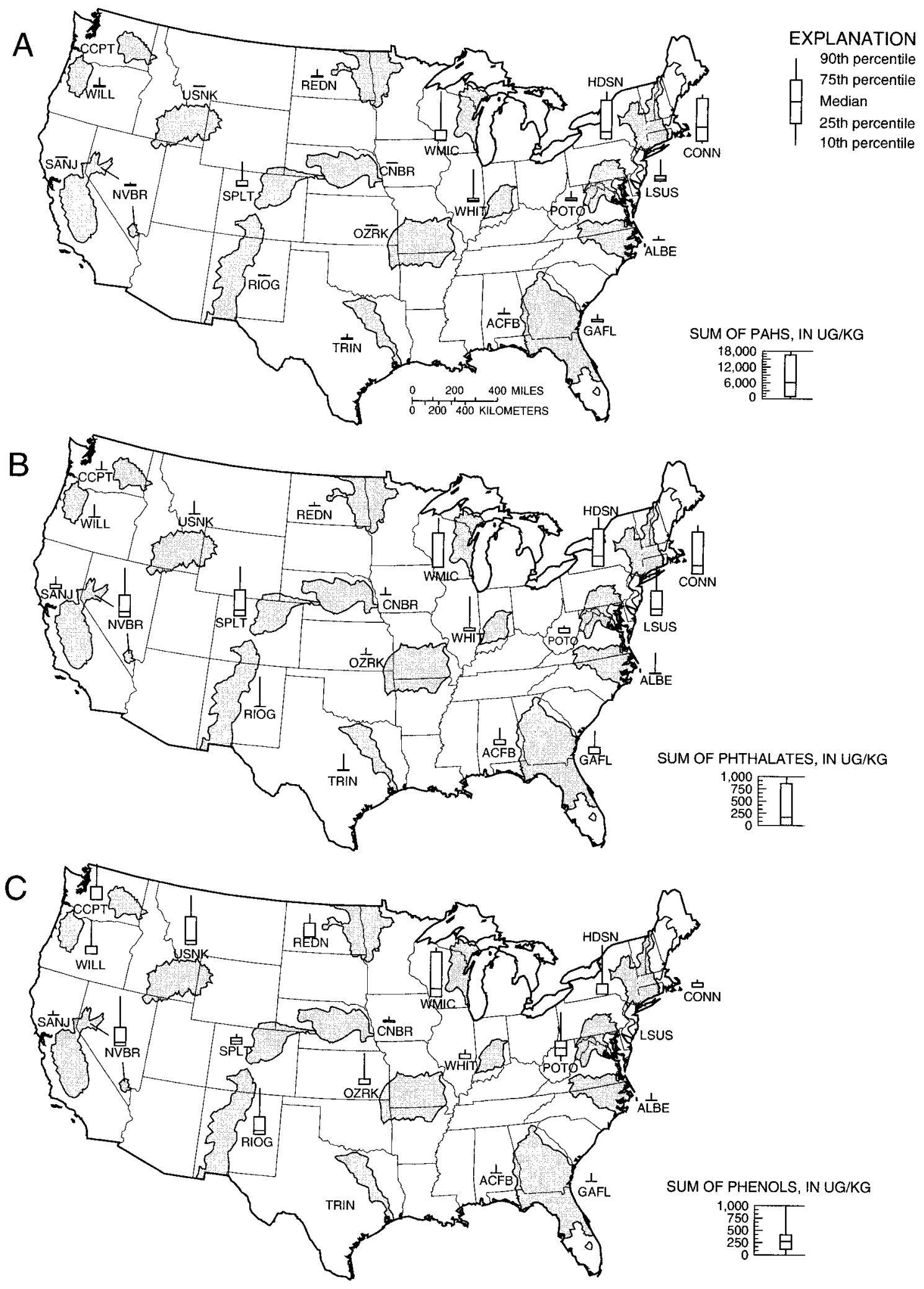

Fig. 3. Ranges in the sum of semivolatile organic compounds in 20 major river basins. See text for site abbreviations.

with probable adverse effects are in nine river basins: CONN, HDSN, LSUS, POTO, SPLT, WHIT, WMIC, Georgia-Florida Coastal Plain (GAFL), and the Willamette Basin (WILL). Adverse effects are possible at $16.2 \%$ of sites; one or more of these sites are in each of the river basins except Central Nebraska Basins (CNBR), Rio Grande Valley (RIOG), and Upper
Snake River Basin (USNK). A median of six SVOCs exceeded the upper screening value at sites with probable adverse effects, and a median of two SVOCs exceeded the lower screening value at sites with possible adverse effects. Adverse effects are unlikely at $76.3 \%$ of sites. However, two upper and six lower screening values are less than the censoring level used 

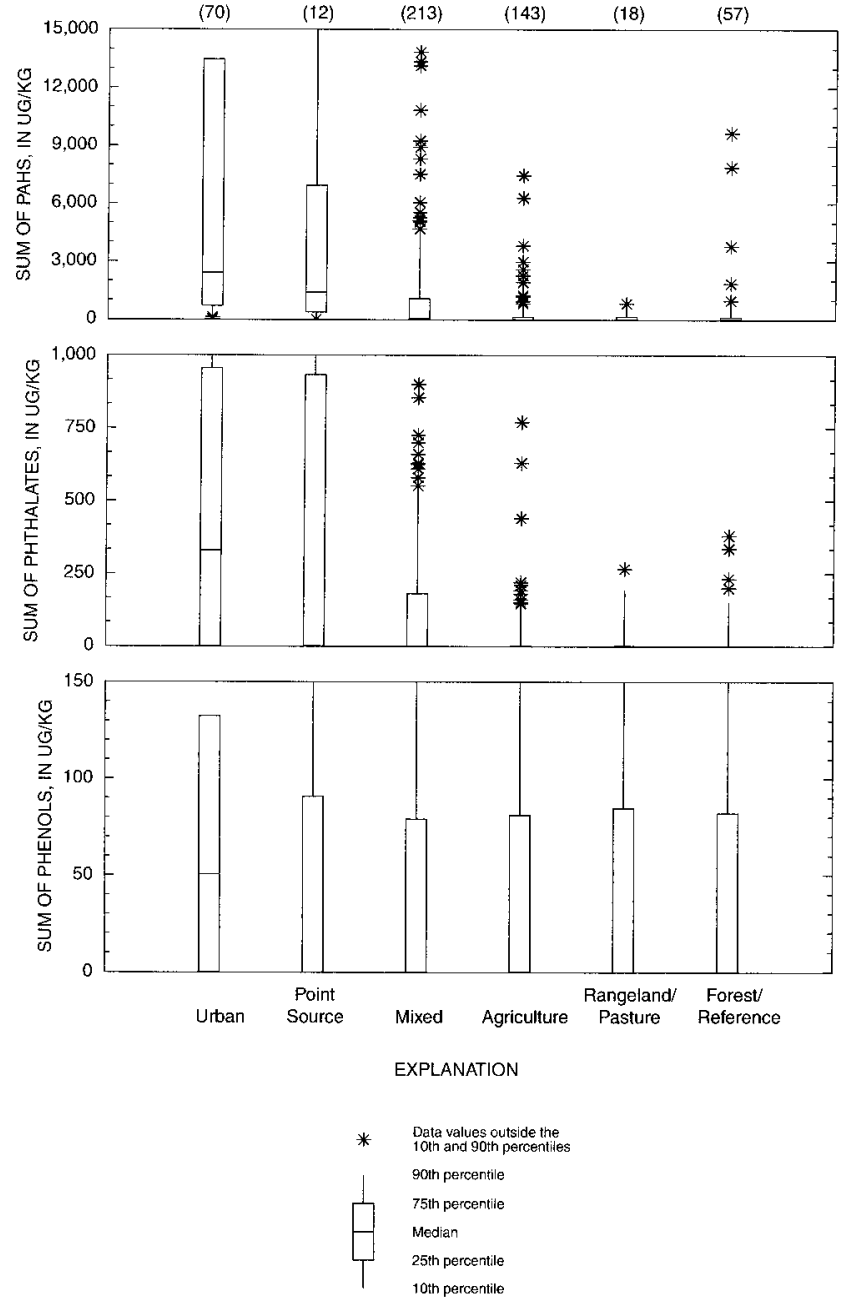

Fig. 4. Ranges in the sum of semivolatile organic compounds (SVOCs) as a function of land use. Only values less than about the 75 th percentile for urban land use are shown for easier comparison.

in this study, so the percentage of sites with probable or possible adverse effects could be underestimated. The NSQS found that adverse effects were probable at $26 \%$ of sites, possible at $49 \%$ of sites, and unlikely at $25 \%$ of sites. The NSQS distinguished sites using screening values for pesticides and trace elements in addition to SVOCs. Including screening values for these contaminants would likely increase the percentage of NAWQA sites where adverse effects are probable or possible.

A rank-sum test indicated that sites with either probable or possible adverse effects have significantly greater urban land use than other sites. Sites with probable adverse effects have a median of $16 \%$ urban land use and sites with possible adverse effects have a median of $8 \%$ urban land use. In comparison, sites with unlikely adverse effects have a median of $2 \%$ urban land use. The low percentage of urban land use that results in probable or possible adverse effects is consistent with NSQS findings. The NSQS found that the percentage of sediment contaminated with PAHs increased sharply when urban land use comprised $5 \%$ or more of a drainage basin [17].

Polycyclic aromatic hydrocarbons and bis(2-ethylhexyl) phthalate accounted for most exceedences of screening values. Probable adverse effects were mostly due to six PAHsbenz $[a]$ anthracene, chrysene, dibenz $[a, h]$ anthracene, fluoran-

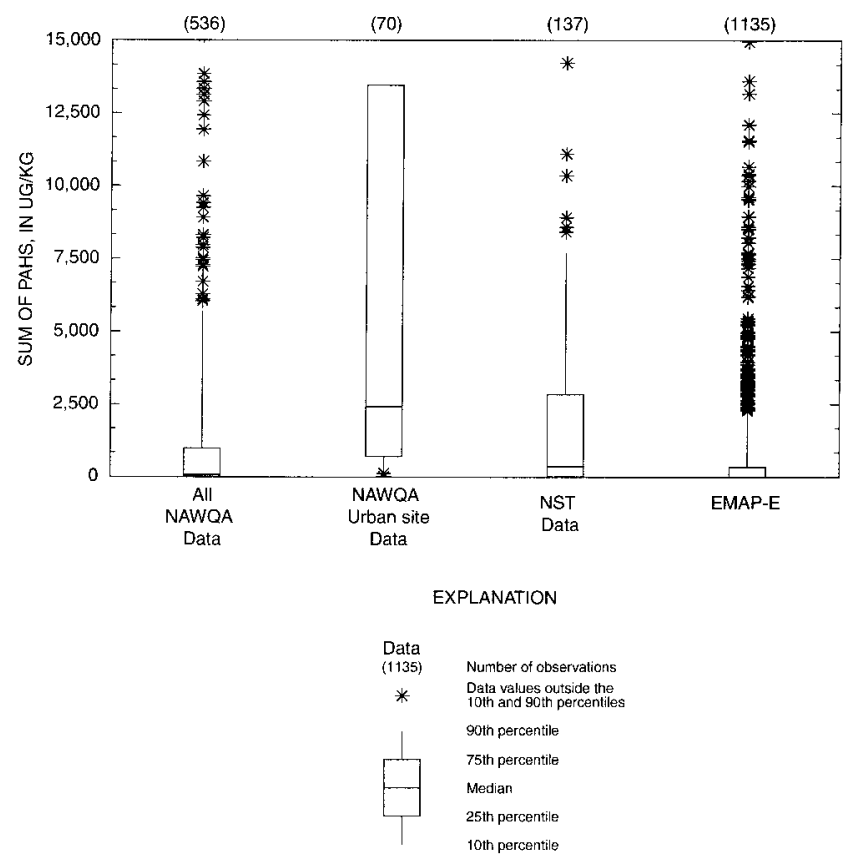

Fig. 5. Comparison of the sum of polycyclic aromatic hydrocarbons (PAHs) in bed sediment among three national studies. National WaterQuality Assessment (NAWQA) data are streambed sediment. Environmental Monitoring and Assessment Program-Estuaries (EMAP-E) data and National Status and Trends (NST) program are marine sediments. The PAHs were summed at a censoring level of $50 \mu \mathrm{g} / \mathrm{kg}$ for equal comparison among studies. Only values $<15,000 \mu \mathrm{g} / \mathrm{kg}$ are shown for easier comparison.

thene, phenanthrene, and pyrene (Table 3). Six other PAHs, total PAHs, and bis(2-ethylhexyl) phthalate exceeded upper screening values at 17 or few sites. Exceedences of the upper screening value for individual PAHs is about twice that for total PAHs. This difference indicates that an SQC only for total PAHs may underprotect aquatic biota. Cluster analysis using PAH detections determined that 19 PAH mixtures with two to nine compounds had $r^{2}$ values of 0.7 or greater (Appendix). Eight of these mixtures have one or more of the six

Table 2. Rank correlations among semivolatile organic compounds (SVOCs) in streambed sediment, percentage of land use, and population density ${ }^{\mathrm{a}}$

\begin{tabular}{|c|c|c|c|c|}
\hline Variable & $\begin{array}{l}\text { Sum of all } \\
\text { SVOCs }\end{array}$ & $\begin{array}{l}\text { Sum of } \\
\text { PAHs }^{\mathrm{b}}\end{array}$ & $\begin{array}{c}\text { Sum of } \\
\text { phthalates }\end{array}$ & $\begin{array}{l}\text { Sum of } \\
\text { phenols }\end{array}$ \\
\hline Sum of PAHs & 0.89 & - & - & - \\
\hline Sum of phthalates & 0.68 & 0.62 & - & - \\
\hline Sum of phenols & 0.51 & 0.27 & 0.26 & \\
\hline \multicolumn{5}{|c|}{ Land use in drainage basin } \\
\hline Urban & 0.48 & 0.52 & 0.42 & $0.08 \mathrm{~A}$ \\
\hline Agriculture & -0.18 & -0.18 & -0.17 & -0.11 \\
\hline Rangeland and pasture & -0.13 & -0.17 & -0.09 & $-0.06 \mathrm{~A}$ \\
\hline Forest & $0.04 \mathrm{~A}$ & $0.04 \mathrm{~A}$ & $0.02 \mathrm{~A}$ & $0.03 \mathrm{~A}$ \\
\hline \multicolumn{5}{|c|}{ Population density in drainage basin and within radius of sample sit } \\
\hline Drainage basin & 0.49 & 0.54 & 0.44 & $0.04 \mathrm{~A}$ \\
\hline $5-\mathrm{km}$ radius & 0.50 & 0.56 & 0.42 & $0.07 \mathrm{~A}$ \\
\hline $10-\mathrm{km}$ radius & 0.49 & 0.56 & 0.42 & $0.05 \mathrm{~A}$ \\
\hline $25-\mathrm{km}$ radius & 0.45 & 0.51 & 0.41 & $0.02 \mathrm{~A}$ \\
\hline $50-\mathrm{km}$ radius & 0.42 & 0.50 & 0.39 & $-0.05 \mathrm{~A}$ \\
\hline $100-\mathrm{km}$ radius & 0.37 & 0.46 & 0.32 & $-0.08 \mathrm{~A}$ \\
\hline
\end{tabular}

${ }^{a}$ Values sharing the same uppercase letter not significant at $\alpha=0.05$.

${ }^{b}$ PAHs $=$ polycyclic aromatic hydrocarbons. 

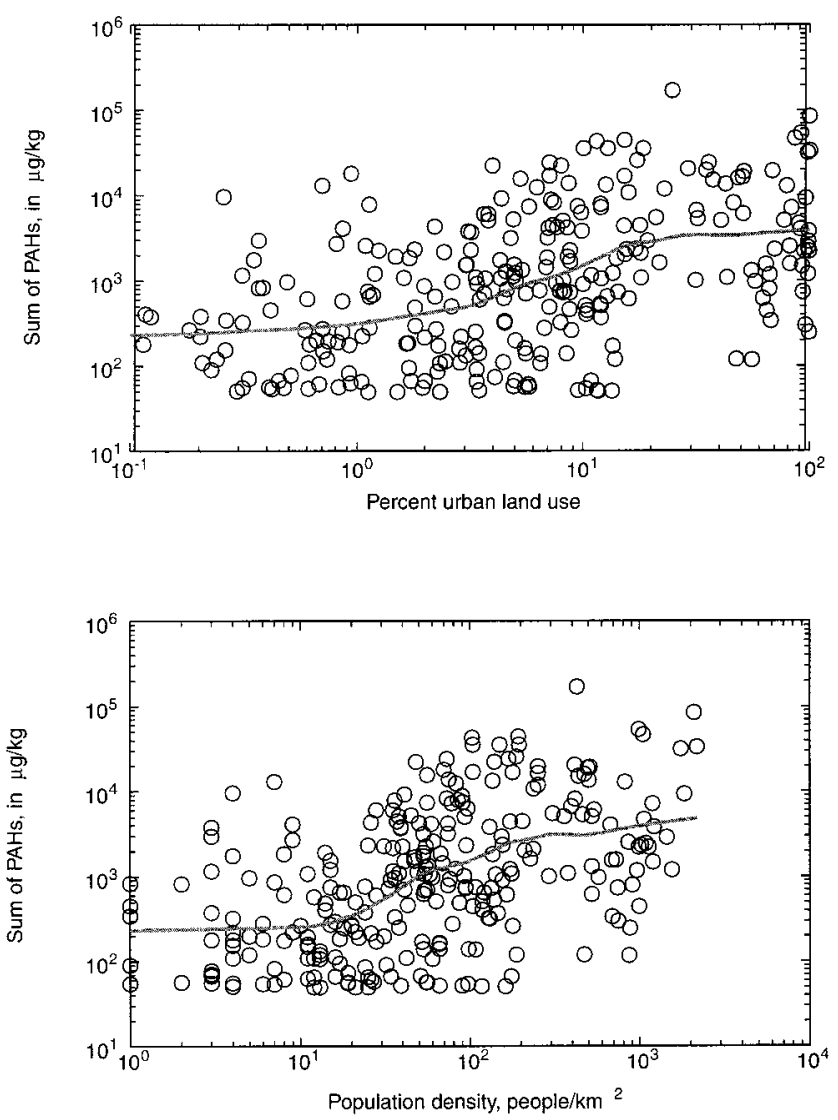

Fig. 6. Relations between the population density and percentage of urban land use in sampled drainage basins and the sum of polycyclic aromatic hydrocarbons (PAHs). Locally weighted scatter-plot smoothing was used to draw lines.

PAHs that most commonly exceeded their upper screening value. Studies of the toxicity of PAH mixtures may want to focus on these commonly co-occurring PAHs.

$p$-Cresol exceeded the lower screening value at 31 sites, and phenol did not exceed the lower screening value at any site. Sites with possible adverse effects due to $p$-cresol are in CONN, GAFL, HDSN, NVBR, OZRK, POTO, REDN, RIOG, USNK, WILL, WMIC, Apalachicola-Chatahoochee-Flint River Basin (ACFB), and the Central Columbia Plateau (CCPT). Goodbred et al. [33] found a significant parametric, inverse correlation between the sum of phenols and 11-ketotestosterone in male carp at a subset of the streambed sites from this study. $p$-Cresol did not exceed the lower screening value at this subset of sites, indicating that SQGs may not identify sites with possible endocrine disruption. Bis-phenol A is the only phenolic compound identified as an endocrine disruptor [11] and was not measured in streambed-sediment samples. Some phthalates and PAHs are endocrine disruptors; however, correlations between biomarkers in carp and the sum of PAHs and sum of phthalates were not significant.

\section{SUMMARY}

The occurrence and potential adverse effects of select SVOCs in streambed sediment were assessed at 536 sites in 20 major river basins across the United States from 1992 to 1995. Fifty-six SVOCs were detected at one or more sites, and one or more SVOCs were detected at $71 \%$ of sites. The northeastern and Great Lakes regions, which have large populations,
Table 3. Exceedence of sediment-quality screening values

\begin{tabular}{|c|c|c|c|c|}
\hline \multirow[b]{2}{*}{ Compound name } & \multicolumn{2}{|c|}{$\begin{array}{l}\text { Lower screening } \\
\text { value }\end{array}$} & \multicolumn{2}{|c|}{$\begin{array}{c}\text { Upper screening } \\
\text { value }\end{array}$} \\
\hline & $\mu \mathrm{g} / \mathrm{kg}$ & $n^{\mathrm{a}}$ & $\mu \mathrm{g} / \mathrm{kg}$ & $n$ \\
\hline \multicolumn{5}{|c|}{ Polycyclic aromatic hydrocarbons } \\
\hline Acenaphthene ${ }^{\mathrm{b}}$ & 6.71 & 53 & 500 & 3 \\
\hline Acenaphthylene ${ }^{\mathrm{b}}$ & 5.87 & 69 & 640 & 4 \\
\hline Anthracene ${ }^{c}$ & 57.2 & 106 & 845 & 14 \\
\hline Benzo $[a]$ anthracene ${ }^{\mathrm{c}}$ & 108 & 108 & 1,050 & 28 \\
\hline Benzo $[b]$ fluoranthene ${ }^{\mathrm{b}}$ & 3,600 & 5 & —d & - \\
\hline Benzo $[k]$ fluoranthene ${ }^{\mathrm{b}}$ & 3,600 & 5 & - & - \\
\hline Benzo $[a]$ pyrene ${ }^{c}$ & 150 & 101 & 1,450 & 17 \\
\hline Benzo $[g h i]$ perylene ${ }^{\mathrm{b}}$ & 720 & 15 & - & - \\
\hline Chrysene ${ }^{\mathrm{c}}$ & 166 & 111 & 1,290 & 31 \\
\hline $\operatorname{Dibenz}[a, h]$ anthracene $^{\mathrm{e}}$ & 33.0 & 101 & 260 & 26 \\
\hline Fluoranthene $\mathrm{e}^{\mathrm{c}}$ & 423 & 78 & 2,230 & 27 \\
\hline Fluorene $^{c}$ & 77.4 & 40 & 536 & 3 \\
\hline Indeno $[1,2,3-c d]$ pyrene ${ }^{b}$ & 690 & 25 & - & - \\
\hline Naphthalene ${ }^{\mathrm{c}}$ & 176 & 9 & 561 & 1 \\
\hline Phenanthrene $^{c}$ & 204 & 82 & 1,170 & 31 \\
\hline Pyrene $^{c}$ & 195 & 104 & 1,520 & 33 \\
\hline Total $\mathrm{PAHs}^{\mathrm{c}}$ & 1,610 & 105 & 22,800 & 14 \\
\hline \multicolumn{5}{|c|}{ Phthalates } \\
\hline bis(2-Ethylhexyl)phthalate ${ }^{b}$ & 182 & 101 & 2,650 & 6 \\
\hline Butylbenzylphthalate & 900 & 1 & $11,000^{\mathrm{f}}$ & 0 \\
\hline Di- $n$-butylphthalate & 1,400 & 0 & $11,000^{\mathrm{f}}$ & 0 \\
\hline Diethylphthalate $^{\mathrm{b}}$ & 200 & 0 & $630^{\mathrm{f}}$ & 0 \\
\hline Dimethylphthalate $^{\mathrm{b}}$ & 160 & 0 & - & - \\
\hline Di- $n$-octylphthalate & 6,200 & 0 & - & - \\
\hline \multicolumn{5}{|c|}{ Phenols } \\
\hline$p$-Cresol ${ }^{\mathrm{b}}$ & 670 & 31 & - & - \\
\hline Phenol $^{\mathrm{b}}$ & 420 & 0 & - & - \\
\hline Pentachlorophenol ${ }^{\mathrm{b}}$ & 360 & 4 & - & - \\
\hline \multicolumn{5}{|c|}{ Halo- and nitroso-compounds } \\
\hline 4-Bromophenyl-phenylether ${ }^{\mathrm{b}}$ & $1,300^{\mathrm{f}}$ & 0 & - & - \\
\hline 1,2-Dichlorobenzene $\mathrm{e}^{\mathrm{b}}$ & 50 & 3 & $340^{\mathrm{f}}$ & 0 \\
\hline 1,3-Dichlorobenzene ${ }^{\mathrm{b}}$ & $1,700^{\mathrm{f}}$ & 0 & - & - \\
\hline 1,4-Dichlorobenzene ${ }^{\mathrm{b}}$ & 110 & 2 & $350^{\mathrm{f}}$ & 0 \\
\hline Hexachlorobenzene $e^{b}$ & 22 & 0 & - & - \\
\hline Hexachlorobutadiene ${ }^{\mathrm{b}}$ & 11 & 0 & - & - \\
\hline Hexachloroethane $^{\mathrm{b}}$ & $1,000^{\mathrm{f}}$ & 0 & - & - \\
\hline$N$-Nitrosodiphenylamine ${ }^{\mathrm{b}}$ & 28 & 7 & - & - \\
\hline 1,2,4-Trichlorobenzene $e^{\mathrm{b}}$ & 51 & 1 & $9,200^{\mathrm{f}}$ & 0 \\
\hline Total $N$ out of 536 & - & 127 & - & 40 \\
\hline
\end{tabular}

${ }^{\text {a }} n=$ number of sites.

${ }^{\mathrm{b}}$ Marine sediment-quality guidelines [17].

${ }^{\mathrm{c}}$ Freshwater sediment-quality guidelines [18].

$\mathrm{d}-=$ does not exist or apply.

${ }^{\mathrm{e}}$ Lower screening value is freshwater, and upper screening value is marine, sediment-quality guideline.

${ }^{\mathrm{f}}$ Screening value assuming $1 \%$ organic carbon.

and large metropolitan areas, such as Las Vegas, Nevada, and Denver, Colorado, have the highest SVOC concentrations.

Polycyclic aromatic hydrocarbons were detected most frequently and at the highest concentrations, and their detection frequencies significantly correlated with physical/chemical properties. Concentrations of PAHs and phthalates were about 10 times higher at sites influenced by urban activities than at sites in agricultural, rangeland/pasture, and relatively undisturbed areas. Semivolatile organic compounds were positively correlated with the percentage of urban land use and population density in the drainage basin. Polycyclic aromatic hydrocarbon concentrations begin to increase when urban land use is about 1 to $3 \%$ of the drainage basin and population density is about 10 to 20 people $/ \mathrm{km}^{2}$. Correlations between the sum of PAHs and population density decrease with distances greater than 10 
$\mathrm{km}$ around sample sites, indicating that urban activities near sample sites affect sediment quality.

Adverse effects to aquatic organisms are probable at $7.5 \%$ and possible at $16.2 \%$ of the sites. Most of the potential for adverse effects is due to PAHs. The median percentage of urban land use was $8 \%$ at sites with possible adverse effects and $16 \%$ at sites with probable adverse effects. Urbanization profoundly affects sediment quality, even though it comprised a small percentage of most drainage basins.

\section{REFERENCES}

1. Gilliom RJ, Alley WM, Gurtz ME. 1995. Design of the National Water-Quality Assessment Program: Occurrence and distribution of water-quality conditions. Circular 1112. U.S. Geological Survey, Reston, VA.

2. Wong CS, Capel PD, Nowell LH. 2000. Organochlorine pesticides and PCBs in stream sediment and aquatic biota-Initial results from the National Water-Quality Assessment Program, 19921995. Water Resources Investigations Report. WRIR 00-4053. U.S. Geological Survey, Reston, VA.

3. Rice KC. 1999. Trace element concentrations in streambed sediment across the conterminous United States. Environ Sci Technol 33:2499-2504.

4. Karickhoff SW, Brown DS, Scott TA. 1979. Sorption of hydrophobic pollutants on natural sediments. Water Res 13:241-248.

5. Furlong ET, Vaught DG, Merten LM, Foreman WT, Gates PM. 1996. Methods of analysis by the U.S. Geological Survey National Water Quality Laboratory-Determination of semivolatile organic compounds in bottom sediment by solvent extraction, gel permeation chromatographic fractionation, and capillary-column gas chromatography/mass spectrometry. Open-File Report 95719. U.S. Geological Survey, Reston, VA.

6. Water Environment Federation. 1993. The Clean Water Act of 1987. Alexandria, VA, USA.

7. National Research Council. 1983. Polycyclic Aromatic Hydrocarbons: Evaluation of Sources and Effects. National Academy Press, Washington, DC, USA.

8. Furlong ET, Carpenter R. 1982. Azaarenes in Puget Sound sediments. Geochim Cosmochim Acta 46:1385-1396.

9. Smith JA, Witkowski PJ, Fusillo TV. 1988. Manmade organic compounds in the surface waters of the United States-A review of current understanding. Circular 1007. U.S. Geological Survey, Reston, VA.

10. Neff JM. 1979. Polycyclic Aromatic Hydrocarbons in the Aquatic Environment: Sources, Fates, and Biological Effects. Applied Science, London, UK.

11. Keith LH. 1997. Environmental Endocrine Disruptors: A Handbook of Property Data. John Wiley \& Sons, New York, NY, USA.

12. Colborn T, Clement C, eds. 1992. Chemically-Induced Alterations in Sexual and Functional Development: The Wildlife/Human Connection. Princeton Scientific, Princeton, NJ, USA.

13. U.S. Geological Survey. 1999. The quality of our Nation's waters: Nutrients and pesticides. Circular 1225. Reston, VA.

14. Jett DA, Navoa RV, Lyons MA. 1999. Additive inhibitory action of chlorpyrifos and polycyclic aromatic hydrocarbons on acetylcholinesterase activity in vitro. Toxicol Lett 105:223-229.

15. Field LJ, MacDonald DD, Norton SB. 1999. Evaluating sediment chemistry and toxicity data using logistic regression modeling. Environ Toxicol Chem 18:1311-1322.

16. O'Connor TP, Daskalakis KD, Hyland JL, Paul JF, Summers JK.
1998. Comparisons of sediment toxicity with predictions based on chemical guidelines. Environ Toxicol Chem 17:468-471.

17. U.S. Environmental Protection Agency. 1997. The incidence and severity of sediment contamination in surface waters of the United States. Vol 1: National sediment quality survey. EPA 823-R-97006. Washington, DC

18. MacDonald DD, Ingersoll CG, Berger TA. 2000. Development and evaluation of consensus-based sediment quality guidelines for freshwater ecosystems. Arch Environ Contamin Toxicol 39: $20-31$.

19. Mackay D, Shiu WY, Ma KC. 1992. Illustrated Handbook of Physical-Chemical Properties and Environmental Fate for Organic Chemicals, Vols I and II. Ann Arbor Science, Ann Arbor, MI, USA.

20. Shelton LR, Capel PD. 1994. Guidelines for collecting and processing samples of streambed sediment for analysis of trace elements and organic contaminants for the National Water-Quality Assessment Program. Open-File Report 94-458. U.S. Geological Survey, Reston, VA.

21. U.S. Environmental Protection Agency. 1992. Guidelines establishing test procedures for the analysis of pollutants (Appendix $\mathrm{B}$ : Definition and procedure for the determination of the method detection limit-Revision 1.11). 40 CFR, Part 136. U.S. Government Printing Office, Washington, DC.

22. Helsel DR, Hirsch RM. 1992. Statistical Methods in Water Resources. Elsevier, New York, NY, USA.

23. U.S. Environmental Protection Agency. 1998. Contaminated sediment news. EPA-823-N-97-007 20:11. Washington, DC.

24. SAS Institute. 1993. SAS ${ }^{\circledR / S T A T ~ U s e r ' s ~ G u i d e, ~ V e r ~ 6, ~ 4 t h ~ e d, ~ V o l ~}$ 1. Cary, NC, USA.

25. Macauley JM, Summers JK, Heitmuller PT, Engle VD, Adams AM. 1996. Statistical summary: EMAP-Estuaries Louisianian Province-1993. EPA/620/R-96/003. U.S. Environmental Protection Agency, Gulf Breeze, FL.

26. Strobel CJ, Buffum HW, Benyi SJ, Petrocelli EA, Reifsteck DR, Keith DJ. 1995. Statistical summary: EMAP-Estuaries Virginian Province-1990-1993. EPA/620/R-93-026. U.S. Environmental Protection Agency, Narragansett, RI.

27. Daskalakis KD, O'Connor TP. 1995. Normalization and elemental sediment contamination in the coastal United States. Environ Sci Technol 29:470-477.

28. Long ER, MacDonald DD, Smith SL, Calder FD. 1995. Incidence of adverse biological effects within ranges of chemical concentrations in marine and estuarine sediments. Environ Manag 19: 81-97.

29. Landrum PF, Robbins JA. 1990. Bioavailability of sediment-associated contaminants to benthic invertebrates. In Baudo R, Giesy J, Muntau H, eds, Sediments: Chemistry and Toxicity of In-Place Pollutants. Lewis, Ann Arbor, MI, USA, pp 237-263.

30. U.S. Bureau of the Census. 1994. Appendix B: Metropolitan areas with component counties and codes. In County and City Data Book 1994, a Statistical Abstract Supplement. CD-CCDB-94 [digital data set]. U.S. Department of Commerce, Economics and Statistics Administration, Washington DC.

31. Prager JC. 1995. Environmental Contaminant Reference Databook, Vol 1. Van Nostrand Reinhold, New York, NY, USA.

32. Verschueren K. 1983. Handbook of Environmental Data on Organic Chemicals. Van Nostrand Reinhold, New York, NY, USA.

33. Goodbred SL, Gilliom RJ, Gross TS, Denslow NP, Bryant WL, Schoeb TR. 1997. Reconnaissance of $17 \beta$;-ketotestosterone, vitellogin, and gonad histopathology in common carp of United States Streams: Potential for contaminant-induced endocrine disruption. Open-File Report 96-627. U.S. Geological Survey, Reston, VA. 


\section{APPENDIX}

Commonly co-occurring polycyclic aromatic hydrocarbons (PAHs) in streambed sediment in the United States

\begin{tabular}{|c|c|}
\hline$r^{2 \mathrm{a}}$ & PAHs \\
\hline 1.00 & Benzo $[b]$ fluoranthene; benzo $[k]$ fluoranthene \\
\hline 1.00 & Fluoranthene, ${ }^{\mathrm{b}}$ pyrene ${ }^{\mathrm{b}}$ \\
\hline 1.00 & Benzo $[a]$ anthracene, ${ }^{\mathrm{b}}$ chrysene $^{\mathrm{b}}$ \\
\hline 0.99 & Anthracene, phenanthrene $\mathrm{e}^{\mathrm{b}}$ \\
\hline 0.98 & $\begin{array}{l}\text { Benzo }[b] \text { fluoranthene, benzo }[k] \text { fluoranthene, ben- } \\
\text { zo }[a] \text { pyrene }\end{array}$ \\
\hline 0.97 & 1-Methylphenanthrene, 4,5-methylphenanthrene \\
\hline 0.96 & 1-Methylpyrene, 2-methylanthracene \\
\hline 0.95 & Benzo $[g h i]$ perylene, dibenzo $[a, h]$ anthracene $^{\mathrm{b}}$ \\
\hline 0.93 & $\begin{array}{l}\text { Benzo }[a] \text { anthracene, }{ }^{\text {b }} \text { benzo }[b] \text { fluoranthene, ben- } \\
\text { zo }[k] \text { fluoranthene, benzo }[a] \text { pyrene, chrysene }{ }^{\mathrm{b}}\end{array}$ \\
\hline 0.92 & 1,6-Dimethylnaphthalene, 2,3,6-trimethylnaphthalene \\
\hline 0.90 & 9H-Fluorene, acenaphthene \\
\hline 0.88 & Anthracene, fluoranthene, ${ }^{\mathrm{b}}$ phenanthrene, ${ }^{\mathrm{b}}$ pyrene $^{\mathrm{b}}$ \\
\hline 0.86 & $\begin{array}{l}\text { Dibenzothiophene, 1-methylphenanthrene, 4,5-methyl- } \\
\text { phenanthrene }\end{array}$ \\
\hline 0.84 & 9H-Fluorene, acenaphthene, acenaphthylene \\
\hline 0.82 & 1,2-Dimethylnaphthalene, 2-ethylnaphthalene \\
\hline 0.80 & $\begin{array}{l}\text { Benzo }[g h i] \text { perylene, dibenzo }[a, h] \text { anthracene, }{ }^{\mathrm{b}} \text { in- } \\
\text { deno }[1,2,3-c d] \text { pyrene }\end{array}$ \\
\hline 0.77 & 1-Methyl-9H-fluorene, naphthalene \\
\hline 0.75 & $\begin{array}{l}\text { Dibenzothiophene, 2-methylanthracene, 1-methylphenan- } \\
\text { threne, 4,5-methylphenanthrene, 1-methylpyrene }\end{array}$ \\
\hline 0.72 & $\begin{array}{l}\text { Anthracene, benzo }[a] \text { anthracene, }{ }^{\mathrm{b}} \text { benzo }[b] \text { fluoranthene, } \\
\text { benzo }[k] \text { fluoranthene, benzo }[a] \text { pyrene, chrysene, }{ }^{\mathrm{b}} \text { fluor- } \\
\text { anthene, }{ }^{\mathrm{b}} \text { phenanthrene, }{ }^{\mathrm{b}} \text { pyrene }{ }^{\mathrm{b}}\end{array}$ \\
\hline
\end{tabular}

a $r^{2}=$ correlation coefficient.

${ }^{\mathrm{b}} \mathrm{PAHs}$ that most commonly exceeded their upper screening value. 